\title{
PELATIHAN CLOUD COMPUTING TERHADAP GURU SEKOLAH
}

\author{
Harry Dhika ${ }^{1}$, Fitriana Destiawati ${ }^{2}$, Musa Jaya ${ }^{3}$ \\ ${ }^{1,2,3)}$ Program Studi Informatika, Fakultas Teknik dan Ilmu Komputer, Universitas Indraprasta PGRI \\ e-mail: dhikatr@yahoo.com ${ }^{1}$, honeyzone86@gmail.com ${ }^{2}$, musajaya.here@gmail.com ${ }^{3}$
}

\begin{abstract}
Abstrak
Mitra merupakan guru sekolah dasar SD Negeri di Jakarta, kegiatan diusulkan dalam pengabdian dengan tujuan memberikan bantuan ilmu pengetahuan terhadap guru sehingga dalam proses pembelajaran dapat lebih mudah, tujuan lain untuk membantu memberikan informasi kepada guru agar siswa dapat mengumpulkan tugas melalui fasilitas cloud computing. Disamping tujuan itu terdapat tujuan lain yakni untuk mempermudah guru dalam memanajemen atau melakukan pengolahan data ketika pembelajaran dimulai. Pengabdian dilakukan di sekolah dengan metode praktikum atau workshop langsung pada guru di sekolah dasar dengan mencoba langsung aplikasi cloud computing yang ada pada layanan seperti dropbox dan google drive. Kegiatan pengabdian diharapkan dapat menyelesaikan beberapa masalah yang ada pada guru dan meningkatkan keterampilan dalam pengolahan data.
\end{abstract}

Kata kunci: Cloud Computing, Sekolah, Guru

\begin{abstract}
Partners are elementary school teachers of SD Negeri in Jakarta, activities proposed in the service to provide knowledge assistance to teachers so that the learning process can be easier, other objectives are to help provide information to teachers so students can collect assignments through facilities cloud computing. Besides that goal, there are other objectives, namely to facilitate teachers in managing or processing data when learning begins. Service is done in schools with practical methods or direct workshops for teachers in primary schools by directly trying existing cloud computing applications on services such as dropbox and google drive. Community service is expected to solve some of the problems that exist in the teacher and improve skills in data processing.
\end{abstract}

Keywords: Cloud Computing, School, Teacher

\section{PENDAHULUAN}

Mitra merupakan sekolah dasar yang ada pada DKI Jakarta. Kegiatan pengabdian dilakukan pada sekolah dasar di daerah Jakarta Timur. Mitra terdiri dari dua lembaga pendidikan dasar. Sasaran utama kegiatan pengabdian ini adalah guru disekolah dasar tersebut. Terdapat beberapa masalah yang ada pada mitra yakni diharapkan dengan adanya fasilitas dari cloud computing sebagai media penyimpanan data dan pengolahan data maka efisiensi dapat tercapai. Seperti halnya materi yang dipersiapkan oleh guru dapat dibuat dirumah dan dikirim melalui fasilitas cloud sehingga dapat lebih terorganisir dan tidak harus menggunakan perangkat keras lainnya seperti flash disk, hal ini tentunya menghemat pengeluaran akan storage service yang harus digunakan oleh seorang pengajar. Kebutuhan lain akan cloud computing adalah dengan adanya fasilitas cloud maka diharapkan data yang telah dibuat dan diupload dalam cloud menjadi lebih mudah dibuka pada berbagai kegiatan dan kesempatan mengajar didalam kelas. Hal sederhana ini sangat bermanfaat ketika guru harus berpindah kelas dari ruang yang satu ke ruang lainnya dalam menyampaikan materi pengajarannya. Data yang mobilitas adalah kebutuhan dasar yang disediakan oleh cloud computing dan menjadi permasalah serta kebutuhan bagi guru dalam menyampaikan pengajaran. Permasalahan lainnya yang ada pada kegiatan pembelajaran yakni sering kali guru melihat dan mengevalusi kegiatan hasil pembelajaran yakni berupa pengumpulan tugas sekolah, pentingnya evalusi berupa pengumpulan hasil tugas yang menjadi evaluasi bagi capaian keberhasilan siswa. Hal ini diharapkan dapat dilakukan dengan mudah oleh guru ketika 
meminta siswa mengerjakan tugas dirumah atau pekerjaan rumahnya dikirim melalui cloud computing.

Tujuan dari pelaksanaan pengabdian ini dari segi dosen yakni untuk menyelesaikan tugas pengabdian yang dilakukan oleh para dosen dalam pelaksanaan tri dharma perguruan tinggi di Universitas Indraprasta PGRI. Sedangkan tujuan dari sudut pandang objek pengabdian yakni dengan dilaksanakannya pengabdian memberikan solusi akan data dalam jumlah besar yang dikelola oleh para guru, memberikan kemudahan dalam bekerja sama dalam mengelolah data menggunakan aplikasi dropbox, memberikan kemudahan dalam akses data dropbox, dimanapun guru berada dan kapanpun guru menginginkan untuk melakukan akses terhadap data pentingnya. Selain tujuan tersebut diatas terdapat beberapa tujuan lainnya yakni untuk mengakses dengan memberikan keamanan pada guru pada data yang dimiliki sehingga seluruh kegiatan dalam berjalan lancar. Dari beberapa tujuan diatas, diharapkan dengan adanya kegiatan pengabdian ini dapat memberikan solusi atas permasalahan para guru terutama dalam pengelolaan data. Solusi yang ditawarkan dalam pengelolaan data yakni dengan melakukan workshop untuk menambah pengetahuan para guru dengan menajemen aplikasi bersama yang di tawarkan oleh dropbox dan konsep yang digunakan yakni manajemen berbasis cloud computing.

Adapun target dari kegiatan pengabdian masyarakat ini adalah guru pada khsusnya Sekolah Dasar Negeri yang berada pada di DKI Jakarta, dari khalayak sasaran yang strategis tersebut diharapkan berbagai informasi yang diberikan dapat digunakan untuk meningkatkan kualitas pelaksanaan pendidikan dilingkungannya sehingga kegiatan pengajaran yang dilakukan guru lebih inovatif, lebih menarik dan tepat sasaran pada siswa-siswinya. Luaran dari kegiatan pengabdian masyarakat ini merupakan jasa dan metode. Jasa dapat berupa pelatihan kepada para guru tentang cloud computing dan metode dapat berupa teknik yang diberikan oleh tim pengabdian dalam mengupload dan mengelola data-data untuk cloud computing.

\section{METODE}

Pelaksanaan pengabdian masyarakat ini memberikan solusi dan alternatif lain dalam metode pembelajaran. Dimana metode dari kegiatan yang dilakukan dengan mengevaluasi sejauh mana kebutuhan utama pada mitra, kemudian dilakukan metode diskusi dan konsultasi. Demonstrasi praktek langsung pada mitra yang didasari oleh evaluasi awal sebagai landasan untuk mengetahui kebutuhan akan cloud computing tersebut dan diakhir pelaksanaanya akan dilakukan evaluasi untuk melihat keberhasilan yang dicapai pada penggunaan aplikasi sistem jaringan tersebut.

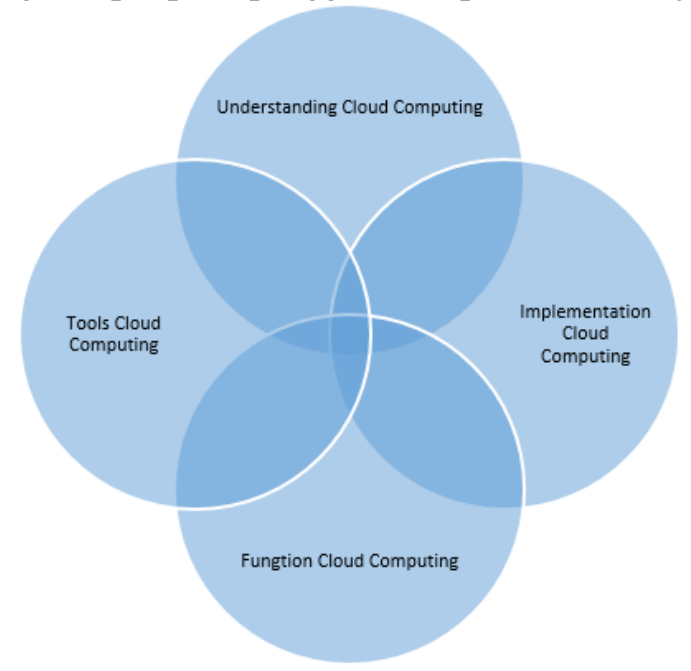

Gambar 1. Metode Penyuluhan

Adapun kegiatan yang menunjukan langkah-langkah solusi atas persoalan yakni dengan melakukan penyuluhan dan memberikan konsultasi pada mitra. Penyuluhan terhadap penggunaan dilakukan secara workhsop atau mitra dalam hal ini melakukan secara langsung mengikuti instrukti yang diberikan oleh tim dosen, khususnya dalam hal penggunaan, login pada cloud dan 
memanajemen file dalam cloud. Partisipasi mitra dalam pelaksanaan program pengabdian masyarakat ini yakni sebagai objek yang menerima workshop atau lokasi dilakukannya instalasi jaringan, mitra dalam hal ini dikhususkan pada guru yang memberikan mendidik siswa siswinya. Materi atau penyampaian cloud computing tersebut diberikan pada guru di sekolah yang ada pada guru secara langsung.

Terdapat banyak metode pelatihan yaitu arahan instruktur (instructor-led), studi kasus (case stud), pemodelan perilaku (behaviour modeling), permainan peran (role-playing), permainan bisnis (business games), in basket training, on the job training, rotasi pekerjaan, magang (internship)(Arikunto et al., 2014). Sementara itu, jenis-jenis metode pelatihan menurut (Dessler, 2017), yaitu on the job training (OJT), magang, belajar secara informal, job instruction training (JIT), pengajaran, pengajaran yang terprogram, teknik pelatihan kemempuan membaca dan menulis, pelatihan dengan audio visual, pelatihan dengan simulasi, pelatihan berbasis komputer, dan pelatihan jarak jauh berbasis internet.

\section{HASIL DAN PEMBAHASAN}

Sebuah jaringan cloud computing dapat didefinisikan sebanyak lima atribut seperti skalabilitas besar-besaran, multi-tenancy (berbagi informasi), fleksibel, informasi dimana-mana dan sumber daya informasi pribadi. Cloud computing memungkinkan pengguna untuk mengakses server remote host pada internet untuk menyimpan dan mengolah data. model cloud computing dapat diklasifikasikan menjadi tiga jenis seperti SaaS, PaaS, IaaS serta model penggunaannya yang berbeda diklasifikasikan menjadi pribadi, Publik, dan Hybrid. Karena kemudahan dari dari cloud computing untuk semua end user. (Manogaran et al., 2016). Cloud Computing juga merupakan teknologi berbasis web yang memungkinkan kita meakukan akses kepada perangkat lunak, perangkat keras, data atau storage data, serta komputasi proses secara langsung (Murah, 2012). Cloud Computing memiliki karakteristik teknologi yang bertujuan memfasilitasi jaringan yang nyaman untuk akses ke koleksi komputing yang sudah terkonfigurasi dengan terhubung koneksi internet (Mutia, 2016).

Banyak sekali yang dapat dilakukan oleh cloud computing, seperti salah satu fungsinya yakni melakuakn translate document dari bahasa asing ke bahasa asing lainnya atau dari bahasa arab ke bahasa lainnya (El-Gayyar et al., 2015). Bahkan perangkat cloud computing dapat di terapkan dalam konsep mobile yang kedepannya dapat diakses oleh para guru disekolah menggunakan handphone dan dapat dibuka oleh siswa disekolah agar pembelajaran lebih optimal (Orsini et al., 2016). Berikut ini adalah konsep yang dapat digunakan pada cloud computing.

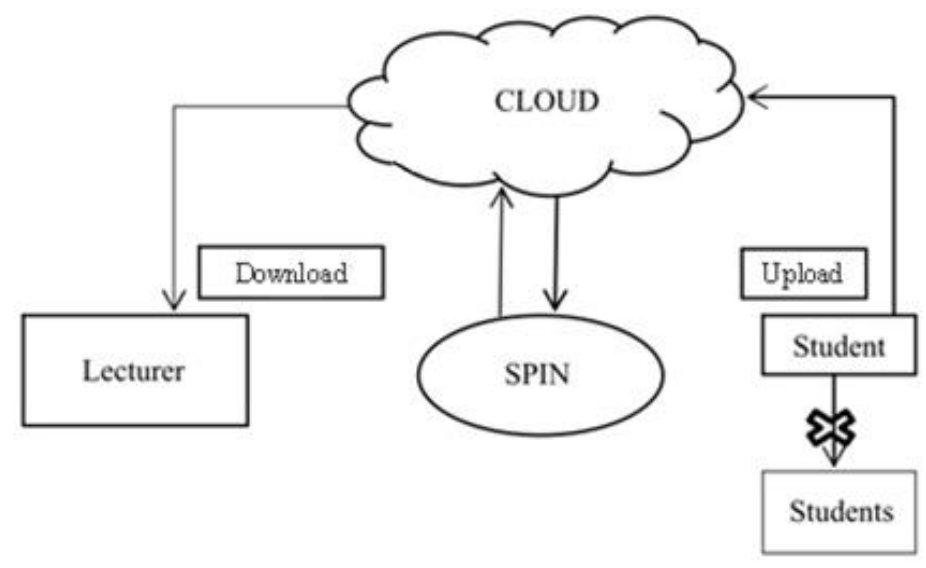

Gambar 2. Konsep Cloud Computing (Murah, 2012)

Semua siswa yang diberikan tugas oleh guru dapat mengupload tugas menggunakan cloud computing sehingga guru dapat memonitoring tugas siswanya. Seluruh layanan dan fasilitas dapat dari penyedia layanan cloud diantaranya dropbox. 


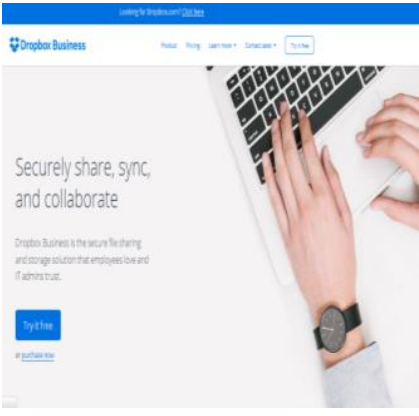

Gambar 3. Dropbox, free cloud computing

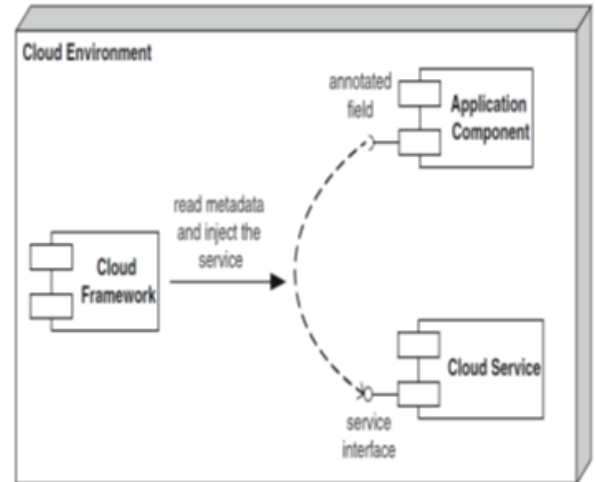

Gambar 4.Cloud Meta data

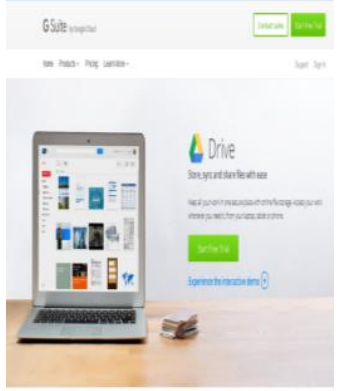

Gambar 5. Google Drive, cloud

Para guru akan melakukan uji coba cloud computing dengan kedua fasilitas cloud diatas dengan melakukan login langsung dengan identitas masing-masing sehingga dapat langsung menggunakan layanan cloud untuk kepentingan pengajaran dalam kelas. Kegiatan ini sangat baik sekali untuk menambah wawasan para guru akan cloud computing oleh karena itu perlunya penyuluhan tambahan pada SD Negeri. Melihat tujuan dari penyelenggaraan pendidikan pada SD Negeri yakni memberikan pendidikan di lingkungan siswa sekolah dasar tentunya dengan perkembangan teknologi cloud diperlukan sebuah strategi dan teknik dalam melaksanakan pengajaran yang baik.

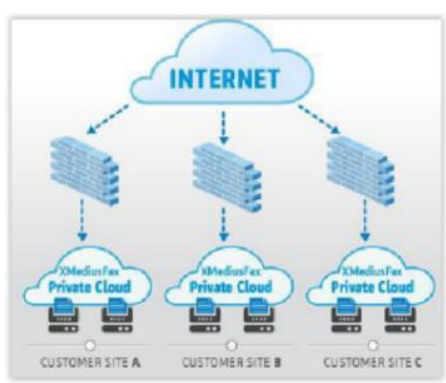

Gambar 6. Cloud Computing Sinergis

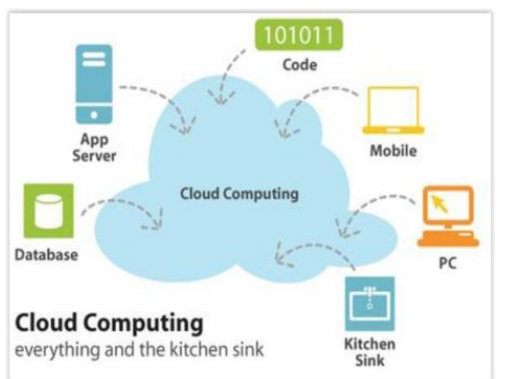

Gambar 7. Public Cloud (Pradhan et al., 2016)

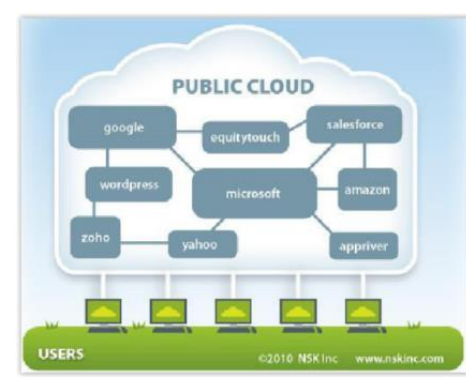

Gambar 8. Private Cloud

Terdapat beberapa perangkat keras yang digunakan pada objek pengabdian, diantaranya adalah sebuah laptop, dan beberapa koneksi internet. Khususnya pada penggunaan Dropbox (Synchronizing, Sharing, dan Backup), Mega (Synchronizing, Sharing, dan Backup), serta Google Apps (Google Drive, Google Docs, Google Sheets, Google Slides dan Google Forms E-Mail, atau Surat Elektronik (surel)(Aryotejo et al., 2018), dari seluruh perangkat cloud tersebut yang paling banyak diimplementasikan penggunaan google cloud dan dropbox. Penggunaan komputer atau laptop tidak memiliki batasan spesifikasi khusus. Hal tersebut dikarenakan cloud computing bekerja menggunakan fasilitas internet dan computer saat ini seluruhnya sudah mendukung fasilitas cloud. Perangkat lunak yang dibutuhkan yakni aplikasi dropbox dan google drive.

\section{Dropbox}

Dropbox adalah cloud computing yang favorit digunakan karena kemudahannya, dapat diandalkan dan mudah diatur konfigurasinya. File diupload pada cloud dan pengguna dapat mengaksesnya kapan saja dari web, aplikasi desktop atau mobile. Pengguna dapat menyimpan file jenis apa pun di dalam dropbox, dengan mengunggah ke web dropbox, aplikasi desktop atau mobile. Aplikasi tersebut tinggal di sistem file, sehingga pengguna dapat dengan mudah mengelola file dari komputer atau mobile ke dalam cloud dan sebaliknya. Layanan ini otomatis dan cepat sinkronisasi file pada semua perangkat yang terhubung dengan dropbox, sehingga pengguna dapat akses semua file dengan mudah di mana saja. Ukuran pada file yang diunggah ke dropbox tidak 
memiliki batasan untuk aplikasi desktop ataupun seluler, tetapi file besar dapat membutuhkan waktu lama untuk diupload, tergantung pada koneksi internet. Proses instalasi dropbox cukup sederhana, tidak membutuhkan waktu lama.

\section{Google Drive}

Google merupakan penyimpanan cloud di drive. Pengolahan data dapat dilakukan pengguna dengan menggunakan layanan ini, termasuk pembuatan dokumen pengolah kata, pengolah angka atau spreadsheet, dan membuat slide presentasi, kapasitas untuk google drive memiliki ruang penyimpanan hingga 15GB gratis(Agus et al., 2019). Jika sudah memiliki akun google, sudah dapat mengakses google drive. Pengguna hanya perlu pergi ke drive.google.com dan mengaktifkan layanan. Dalam menggunakan google drive pengguna harus memiliki akun Google. Penggunaan gmail memudahkan dalam penyimpanan lampiran langsung ke drive. Aplikasi ini dapat mencadangkan foto secara otomatis, tanpa perlu aplikasi tambahan seperti google foto. Ketika menggunakan google drive, fasilitas office untuk membuat dokumen, spreadsheet, atau presentasi ini dapat digunakan dengan baik oleh guru dengan penyimpanan bahan ajar atau keperluan yang lainnya di dalam cloud.

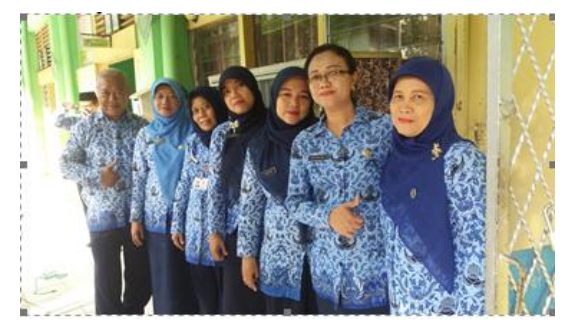

Gambar 9. Para Guru Peserta Pelatihan

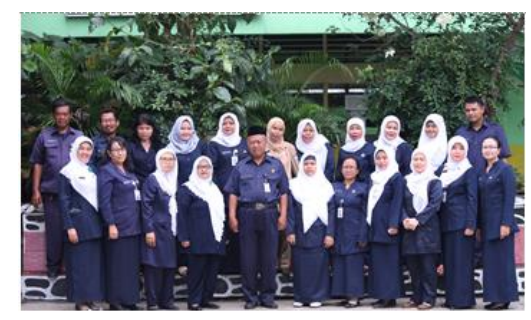

Gambar 10. Para Guru Peserta Pelatihan Bersama Kepala Sekolah

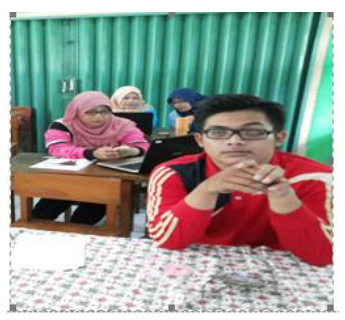

Gambar 11. Para Guru Peserta Pelatihan Cloud

Dari tahapan yang dilakukan diatas ditemukan bahwa penggunaan cloud sangat membantu dalam mengerjakan tugas dimanapun kita berada dengan kelompok yang ada khususnya pada lingkungan sekolah yang tentunya memiliki banyak pekerjaan dan tugas sebagai seorang guru. Hasil yang dicapai dengan diadakannya pengabdian ini adalah dengan membangun pemahaman kepada para guru tentang pentingnya cloud computing sebagai berikut:

1. Pekerjaan administrasi saat ini sudah terhubung, dengan adanya cloud pelaksanaan semakin lebih mudah dan berkelompok.

2. Komunikasi data dalam mengerjakan tugas menjadi lebih ringan dan dapat dilakukan dengan berkelompok, seperti komunikasi antar basis data.

3. Melalui jaringan cloud yang telah dibuat, kedepannya diharapkan dapat mengatur dan mengendalikan dan menyelesaikan tugas secara bersama walau berada pada lokasi yang berbeda.

\section{SIMPULAN}

Seiring dengan kemajuan perkembangan teknologi seorang pengajar terus dituntut untuk belajar sehingga dapat mengikuti perkembangan zaman dengan baik dan memberikan pengetahuannya pada siswa-siswinya dengan harapan dapat memberikan pendidikan dan pengetahuan yang baik, kemudahan dalam mengerjakan tugas dapat diakomodir oleh fasilitas cloud computing yang disediakan oleh dropbox. Seluruh kegiatan berbasis cloud dan dapat dilaksanakan berkelompok sehingga jumlah pekerjaan yang banyak, menumpuk dan berat dapat diselesaikan bersama dengan semangat gotong royong dengan dropbox. 


\section{SARAN}

Pada saat kunjungan ditemukan beberapa hal yang menjadi perhatian dan salah satu diantaranya adalah antusias yang tinggi untuk pelaksanaan pengabdian. Kedepannya diharapkan para tim diminta untuk membawakan materi terkait bahasan dengan mengacu pada tugas guru misalnya dengan membawakan materi dalam membuat file presentasi yang berguna bagi pengurusan kepangkatan seorang guru yang tentunya guna meningkatkan pengetahuan guru serta implmentasinya kepada peserta didik.

\section{UCAPAN TERIMA KASIH}

Penulis mengucapkan terima kasih kepada instansi yang telah memberi dukungan financial terhadap pengabdian ini.

\section{DAFTAR PUSTAKA}

Agus, I., Destiawati, F., \& Dhika, H. (2019). Perbandingan Cloud Computing Microsoft Onedrive , Dropbox, dan Google drive. 12(58), 20-27.

Arikunto, S., Ghozali, Sugiyono, Vardaro, M. J., Systems, H. I. T., AG, H. T., Jari, A., Pentti, M., Information, B. G., Procedure, T., Voltage, H., Procedure, T., Chen, P. C., Salcedo, R., Zhu, Q., De Leon, F., Czarkowski, D., Jiang, Z. P., Spitsa, V., ... Kartika Dewi, A. (2014). Manajemen Sumber Daya Manusia. PT.Bumi Aksara. https://doi.org/10.1017/CBO9781107415324.004

Aryotejo, G., Widiastuti, S., \& Kristiyanto, D. Y. (2018). Pemanfaatan Cloud Computing sebagai Software as a Service Dalam Upaya Peningkatan Kompetensi Teknologi Informasi Guru dan Sistem Tata Kelola PAUD Dabin V Semarang Utilization of Cloud Computing as Software as a Service in Efforts to Improve Information Te. 1, 633-640. http://prosiding.unimus.ac.id/index.php/semnas/article/download/35/35

Dessler, G. (2017). Manajemen Sumber Daya Manusia. In Pelatihan dan Pengembangan. https://doi.org/10.1145/2505515.2507827

El-Gayyar, M. M., Ibrahim, A. S., \& Wahed, M. E. (2015). Translation From Arabic Speech to Arabic Sign Language Based On Cloud Computing. Egyptian Informatics Journal. https://doi.org/10.1016/j.eij.2016.04.001

Manogaran, G., Thota, C., \& Kumar, M. V. (2016). Meta Cloud Data Storage Architecture for Big Data Security in Cloud Computing. Procedia Computer Science, 87, 128-133. https://doi.org/10.1016/j.procs.2016.05.138

Murah, M. Z. (2012). Teaching and Learning Cloud Computing. Procedia - Social and Behavioral Sciences, 59, 157-163. https://doi.org/10.1016/j.sbspro.2012.09.260

Mutia, I. (2016). Penerapan Teknologi Komputasi Awan (Cloud Computing) Untuk Pembelajaran Mahasiswa di Perguruan Tinggi. Mutiara, 9(3), 283-292.

Orsini, G., Bade, D., \& Lamersdorf, W. (2016). Generic Context Adaptation for Mobile Cloud Computing Environments. Procedia Computer Science, 94(MobiSPC), 17-24. https://doi.org/10.1016/j.procs.2016.08.007

Pradhan, P., Behera, P. K., \& Ray, B. N. B. (2016). Modified Round Robin Algorithm for Resource Allocation in Cloud Computing. Procedia Computer Science, 85(Cms), 878-890. https://doi.org/10.1016/j.procs.2016.05.278 